\section{BRITISH BOTANIC GARDENS AND} STATIONS.

A MARKED feature of the scientific activities of the past fifty years has been the extensive establishment throughout the British Empire of botanic gardens and botanic stations. The history of such institutions is a long one; it takes us back to the time of the Pharaohs. It is also wide; the Spaniards found, in the Mexico they devastated, establishments of this nature conducted with as much enlightenment and on as elaborate a scale as any then to be met with in Europe.

The motives underlying the creation of such gardens have varied at different times and in different countries. $\mathrm{Up}_{\mathrm{p}}$ to the middle of the sixteenth century the scope of European botanical gardens was mainly confined to the technical task of illustrating as fully as possible what were believed to be the sources of classical simples. During the next hundred years this was extended so as to include such æsthetic and economic novelties as could be made to grow. But by the middle of the eighteenth century, when the Royal Garden at Kew (I759), and the Botanic Garden at St. Vincent in the West Indies $(1764)$, were founded, the purpose of botanical collections had become largely limited to the assemblage of plants interesting because of their rarity.

Presently a healthy reaction against this rather narrow outlook arose, for we find the historical memorandum by Lt.-Col. Kyd, to which the establishment of the famous institution at Calcutta was due (1786), advocating "the propriety of establishing a botanical garden, not for the purpose of collecting rare plants (although they also have their uses) as things of mere curiosity or furnishing articles for the gratification of luxury, but for establishing a stock for disseminating such articles as may prove beneficial to the inhabitants as well as to the natives of Great Britain, and which ultimately may tend to the extension of the national commerce and riches." Already Sir Joseph Banks, with his practical mind, had made representations to the same effect with regard to Kew, urging the utilisation of the Royal Garden as a central institution where information regarding the vegetation of the globe and its economic uses could be accumulated; where useful plants from all quarters could be raised; and whence such plants could be distributed to the overseas possessions of the Crown. Before the close of the first generation of the nineteenth century, many important establishments of the kind had been provided; among these we may note the gardens at Peradeniya in Ceylon, Saharunpur in North-West India, Singapore and Penang in Malaya, Buitenzorg in Java (during the brief occupation of that island by the English), Trinidad in the West Indies, and Sydney in Australia.

The conversion of Kew into the national botanic garden for this country ( $184 \mathrm{I}$ ) gave a new impetus to this salutary activity, and under the active guidance of three eminent directors-Sir W. J. Hooker $\left(184 I^{1-65}\right)$, Sir J. D. Hooker $(1865-85)$, and Sir W. T. ThiseltonDyer (1885-1905) - the tradition established by Banks was vigorously sustained. To this impetus we may attribute the establishment of the famous gardens of Melbourne (1846), Durban (1850), Adelaide (1855), Brisbane (1855), and Jamaica (1857), though in the last case the inability of the local legislature to appreciate the value of science ensured for the garden the fate which had befallen that founded a century earlier in St. Vincent. The great services rendered by Kew to all forms of botanical enterprise have been nowhere more manifest than in the training of those who have proceeded to every quarter of the globe NO. $26 \mathrm{IO}$, VOL. IO4] to take charge of the botanic gardens and stations throughout the Empire.

Since 1869, when NaTURE was founded, the activities in this direction have continued unimpaired. In 1870 the botanic garden at Wellington in New Zealand was founded. In 187 I the abandoned Jamaica garden was re-established and another was created in Bermuda. In 1879 an important botanic garden was founded at Georgetown, in British Guiana.

Between 1886 and 1890 the botanic garden at St. Vincent, which had long been allowed to lie in abeyance, was restored, and new botanic stations were opened in the islands of Barbados, Dominica, Grenada, St. Lucia, and the smaller islands. The last station to be established in this region was that of British Honduras (1892). Profiting by the experience gained in the West Indies, attention was directed to Africa, and Kew has been instrumental in the establishment of botanic stations in our West African Colonies at Lagos (1887), Aburi in the Gold Coast (1890), Old Calabar (I893), Sierra Leone (1895), and Kaduna in Northern Nigeria (19I4). In East Africa the need for a botanic station in Nvasaland was urged by the authorities at Kew, and as a result that at Zomba was founded in I89I. This was followed by the establishment of the botanic garden at Entebbe in Uganda in 1898 . The urgency of the need for such an institution in the East Africa Protectorate it has, for some reason, been more difficult to persuade the authorities concerned to realise. But at last (1918) the beginnings of such an institution as has long been called for have been created at Nairobi. The Government of the Sudan, with a keener appreciation of the value of science, lost no time in estab. lishing a botanic garden at Khartum and a botanic station at Jebelin.

Notable additions to the list of botanic gardens were those founded at Hong Kong in $187 \mathrm{x}$, and at Aberdeen in 1897. But the most important of the creations of recent years is that of a great national botanic garden at Kirstenbosch, Cape Town, in I9r3. This science owes to the enlightened action of the Government of the Union of South Africa, and to the untiring advocacy and exertions of the late Prof. Pearson. This institution bids fair to become in time the "Kew" of South Africa, and gives promise to be one of the most interesting and valuable scientific gardens in the world.

\section{THE SCIENTIFIC AND TECHNICAL DEPARTMENT OF THE IMPERIAL. INSTITUTE.}

I $\mathrm{N}$ furtherance of its principal object of promoting the utilisation of the resources of the Empire, and in order to supplement its other activities in this direction, the Imperial Institute established in 1896 a scientific and technical department under the direction of Prof. Wyndham Dunstan. The history of the formation of that department and of its work in early vears was told by the late Sir Frederick Abel, at that time Director of the Imperial Institute, in the preface to a volume of technical reports and scientific papers published by the institute in 1903. From that account it will be seen that the inception of scientific work at the institute received strong support from his Majesty King Edward and from the Royal Commission of the 185 I Exhibition, whilst the late Lord Playfair was one of its most active supporters.

The principal purpose of the department was to investigate by laboratory researches and technical trials raw materials, and especially those derived from the Empire overseas, as the first step in their commercial utilisation. The work of the department 